\title{
Perspectives of continuing formal education among nurses in selected secondary healthcare facilitiesin Northern Nigeria
}

\author{
Aliyu Adamu ${ }^{1}$, Ibrahim Taiwo Adeleke ${ }^{2,3,4}$, Danjuma Aliyu $^{5}$, Tawheed Mahmud ${ }^{1}$ \\ ${ }^{1}$ Niger State College of Nursing Sciences, Bida, Nigeria \\ ${ }^{2}$ Department of Health Information, Federal Medical Centre, Bida, Nigeria \\ ${ }^{3}$ Centre for Health \& Allied Researches,Bida, Nigeria \\ ${ }^{4}$ Health Informatics Research Initiatives in Nigeria,Bida, Nigeria \\ ${ }^{5}$ Department of Nursing Services, Ahmadu Bello University Teaching Hospital, Zaria, Nigeria
}

Email address:

alimuye@yahoo.com (A. Adamu), ibratadeleke_aliseyin@yahoo.com (I. T. Adeleke), aliyudanjuma19@gmail.com (D. Aliyu), mahmu.kakanma.tm@gmail.com (T. Mahmud)

\section{To cite this article:}

AliyuAdamu, Ibrahim Taiwo Adeleke, DanjumaAliyu, Tawheed Mahmud. Perspectives of Continuing Formal Education among Nurses in Selected Secondary Healthcare Facilitiesin Northern Nigeria. American Journal of Health Research. Special Issue: Health Information Technology in Developing Nations: Challenges and Prospects Health Information Technology.Vol. 3, No. 1-1, 2015, pp. 68-73. doi: $10.11648 /$ j.ajhr.s.2015030101.20

\begin{abstract}
Objective: The purpose of this study was to determine registered nurses' perception of continuing formal education (CFE). Methods: A quota sampling was used to recruit 100 registered nurses who attended a mandatory continuing professional development programs in two different locations (Minna and New Bussa) in Niger state, Nigeria. Results:The findings from the study reveal that the participants' major reasons for undertaking continuing formal education were to be current in their specialty $(86.5 \%)$, to develop proficiency necessary to meet patients' needs (95.8\%) and to improve selfconfidence $(95.8 \%)$. The result also shows that the major motivating factors identified by the participants to undertake CFE were encouragement from management $(95.8 \%)$ and funding supports $(94.8 \%)$. Major barriers to undertaking CFE among nurses in this study were lack of funding (97.9\%) and family roles of child bearing and caring (94.8\%).Conclusion: The need for nurses to undertake CFE is well recognized by the participants in this study. However, the managers of healthcare systemsneed to provide nurses with the necessary supports to enable them attend such programs in order to enhance their productivity.
\end{abstract}

Keyword: Continuing Formal Education, Continuing Professional Education, Nurses, Nigeria

\section{Introduction}

Evidenced-based education and development have become matters of interest globally [1-3] especially in healthcare systems where professional performance ultimately depends on the providers' quality of knowledge, skills and motivation [4]. Particularly, nurses focus on the care of individuals, families andcommunities so that they may attain, maintain, or recover optimalhealth and quality of life. They deal with complex human problems and as such, cannot be limited to circumscribed body of knowledge but, avail themselves of every useful source of knowledge [5]. Therefore, the World Health Organization (WHO) [4] has mandated nursesto embraceevidence-basenursing practice and to be competent practitioners with the increasingly informed patients. Societal changes, technological advancement, global trend, rapidly changing healthcare systems and rising profiles of wellinformed healthcare consumers have propelled nurses to improve on their knowledge, sharpens their clinical competency, be more independent and to beautonomous in clinical judgment [6-7]. Healthcare systems revolutions such as health information technology and meaningful use of computer and the internet [8-12], informed consumers demanding rights and service satisfaction[13-15] and the need for better healthcare systems management [16-19] are capable of propellingquests for further education among Nigerian nurses.

Education and training on continuous basis have been 
described [4] as the key investment tools since old skills become obsolete with the advent of new technologies. Stanford [20]described continuing professional education as an active involvement and motivation of the learner in developing and expanding his/her knowledge and understanding through a variety of means that include selfdirected reading.This could be divided into informal education which includes activities such as reading, studying, watching television and working on committees; and formal education of which seminars, conferences and planned educational programs play an important part [21]. Human resources are the most important part of the health system's resource inputs [4] according to the World Health Organization.These providers shouldhave a mastery of technology and be able to access relevant information from the Internet [4]. For nurses to appreciate and embrace continuing education, its concept has to be fully understood and incorporated into the nurse's professional career [22]. Nurse educators are the leading group to integrate the policy with the practice context and in this line; they require additional educational preparation and professional development in order to provide strong leadership [23].Nurse educators must identify a framework for continuous lifelong learning that includes basic education, academic progression, and continuing clinical competencies [7]. In the same vein, organizationsshould invest in the career development of their employees so as to avoid being characterizedby unmotivated employees grossly disinterested in career development and lack of commitment to the organization [4].

Effective continuing education has been linked [24-25] with raised staff morale, increased motivation, staff retention and development ofleadership skills evidenced by the ability to inspire followers, foster confidence and accommodate criticism. It is beneficial to nurses, clients and the healthcare services and can enhance professional education and personal development [26]. It has been reported [27] to have advanced the delivery of better patient care; provided an ability to gain up-to-date knowledge; to question and change practice; promoted academic credibility and it has facilitated a raised professional status. Since the main purpose of continuing nursing education is to facilitate change in nurses' clinical practice [28], it has enhanced participants' activities and provide the opportunity to practice skills capable of facilitating positive change in professional practice and general healthcare outcomes [29].Nurses themselves have indicatedthat[24-25] enhancement of professional knowledge,professional advancement,relief from routine,enhanced social interactionsand acquisition of credentials as some of the reasons to embrace continuing professional education. Other reasons include keeping abreast with professional development, to develop the necessary proficiency to meet patients' needs [3], to develop leadership capabilities and be effective mentors for junior nurses,improved remuneration and promotion [30] and they embrace continuing professional education in order to update their practice [31]. Nurses often consult their managers for support and information [32] hence; the nurse managers should participate in educational activities that offer personal involvement in thinkingabout professional practice and in identifying learning needs [33]. However, studies [34-35, 3] have reported that continuing nursing education has been constrained by various challenges. These include lack of awareness, staff shortages, family commitments, lack of encouragement from managers, lack of funding and structural barriers such as conditions attached to granting study leave, lack of coherent staff development plans and opportunities for promotion, and lack of a supportive work environment.

\subsection{Aim of the Study}

Although much work has been done on perceptions of nurses about continuing professional education, little is known about the views of Nigerian nurses and their perceptions. Thus, this study sought to assess registered nurses' perception of continuing formal education in Niger State, Northern Nigeria.

\section{Methods}

\subsection{Background to the Study Area}

The study was carried out at the venues of Niger State organized mandatory continuing professional development programs (MCPDP) held between $27^{\text {th }}$ and $31^{\text {st }}$ October 2014 at Minna and New Bussa simultaneously. The mandatory program is designed in modules delivered in series of workshops for all the nurses to participate before renewing their professional practicing licenses.

\subsection{Study Design}

This is a cross-sectional survey on perspectives of continuing formal education among nurses at secondary health facilities in Niger State Nigeria.

\subsection{Study Population}

These included registered nurses from virtually all the 25 LGAs who attended the MCPDP module two workshops between $27^{\text {th }}$ and $31^{\text {st }}$ October 2014. Each of the location registered 100 delegates for the workshop.

\subsection{Data Collection Tools}

A survey questionnaire developed by the authors was used to collect the data for this study. The validity and reliability test of the questionnaire was carried out through a pilot survey of twenty nurses randomly selected from two hospitals. The questionnaire comprised of four sections focusing demographic characteristics, reasons for undertaking continuing formal education, motivations to partake in the programs and barriers to effective continuing formal education.

\subsection{Sampling Techniques and Sample Size}

Quota sampling method was used to select 100 (50 from each location) participants for the study. This sampling 
strategy was used to ensure representation of nurses from each local government in the state. The questionnaire was administered on the participants with the aid of two research assistants at the two locations of the workshops.

\subsection{Data Analysis and Management}

Data analysis was done (descriptive) using the Statistical Product and Services Solutions (SPSS 16.0 for windows).

\subsection{Ethics}

Informed consent was obtained from each participant after permission to conduct the study at the venues was granted by the Niger Sate Coordinator of MCPDP.

\section{Results}

\subsection{Participants'Demographic Characteristics}

Ninety six percent of the one hundred questionnaires distributed were returned.The Mean age of the participants was 33 years and the majority of the participants were females $(61.5 \%)$. There were more Senior Nursing Officers in the study than other categories of nurses. Most of the participants $(54.2 \%)$ had only diploma in nursing and 6 $(6.3 \%)$ hold BNSc.

\subsection{Participants' Reasons for Undertaking Continuing Formal Education}

As shown on Table 1, most participants (95.8\%) undertake continuing formal education in order to develop proficiency necessary to meet patients' needs while more than one-third (36.5\%) disagreed with the notion that they engaged in CFE to develop leadership skills.

Table 1. Reason for undertaking continuing formal education

\begin{tabular}{llll}
\hline Variable & $\begin{array}{l}\text { Disagreed } \\
(\%)\end{array}$ & $\begin{array}{l}\text { Agreed } \\
(\%)\end{array}$ & Total (\%) \\
\hline $\begin{array}{l}\text { Keep up-to-date in the area of } \\
\text { specialization }\end{array}$ & $13(13.5)$ & $83(86.5)$ & $96(100)$ \\
$\begin{array}{l}\text { To develop proficiency necessary } \\
\text { to meet patients' needs }\end{array}$ & $4(4.2)$ & $92(95.8)$ & $96(100)$ \\
$\begin{array}{l}\text { To gain knowledge and skills not } \\
\text { obtained during basic nursing }\end{array}$ & $16(16.7)$ & $80(83.3)$ & $96(100)$ \\
$\begin{array}{l}\text { To develop leadership capabilities } \\
\begin{array}{l}\text { To be an effective mentor for } \\
\text { junior nurses/nursing students }\end{array}\end{array}$ & $35(36.5)$ & $61(63.5)$ & $96(100)$ \\
$\begin{array}{l}\text { To enhance personal confidence } \\
\text { To plan a career pathway }\end{array}$ & $4(4.2)$ & $92(95.8)$ & $96(100)$ \\
$\begin{array}{l}\text { To improve prospects of pay } \\
\text { increase and promotion }\end{array}$ & $35(34.5)$ & $61(63.5)$ & $96(100)$ \\
$\begin{array}{l}\text { To obtain an additional } \\
\text { qualification }\end{array}$ & $11(11.5)$ & $85(88.5)$ & $96(100)$ \\
\hline
\end{tabular}

\subsection{Motivators to Undertake Continuing Formal Education}

Fig 1 below shows that most of the participants (95.8\%) credited supports from their institution's management as the major motivation to acquire more knowledge, the majority $(70.8 \%)$ were encouraged by their peers and many $(67.7 \%)$ disagreed that recent success in a study program could motivate them.

\subsection{Barriers Militatingagainst continuing formal education}

Most participants (97.9\%) admitted that lack of funds prevent them from undertaking continuing formal education (Table 2). Other barriers reported include lack of role models in the workplace $(62.5 \%)$ and difficulty in coping with academic work (14.6\%).

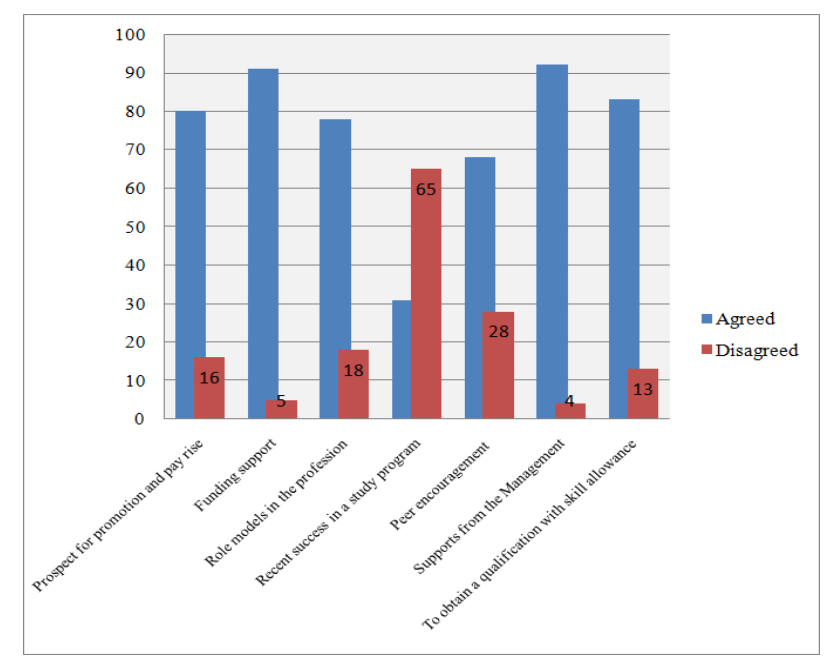

Fig. 1. Reasons for undertaking continuing formal education

Table 2. Barriers to continuing formal education

\begin{tabular}{|c|c|c|c|}
\hline Variable & Disagreed (\%) & Agreed (\%) & Total (\%) \\
\hline Lack of funding & $2(2.1)$ & $94(97.9)$ & $96(100)$ \\
\hline Too much workload & $2728.1)$ & $6971.9)$ & $96(100)$ \\
\hline $\begin{array}{l}\text { Strict conditions attached to the } \\
\text { granting of study leave }\end{array}$ & $23(24)$ & $73(76)$ & $96(100)$ \\
\hline $\begin{array}{l}\text { Lack of cooperation from } \\
\text { management }\end{array}$ & $22(22.9)$ & $74(77.1)$ & $96(100)$ \\
\hline $\begin{array}{l}\text { Family and child care } \\
\text { responsibilities }\end{array}$ & $5(5.2)$ & $91(94.8)$ & $96(100)$ \\
\hline $\begin{array}{l}\text { Lack of opportunities for } \\
\text { promotion }\end{array}$ & $71(74)$ & $25(26)$ & $96(100)$ \\
\hline $\begin{array}{l}\text { Difficulty in coping with } \\
\text { academic work }\end{array}$ & $82(85.4)$ & $14(14.6)$ & $96(100)$ \\
\hline $\begin{array}{l}\text { Lack of role models in the } \\
\text { workplace }\end{array}$ & $36(37.5)$ & $60(62.5)$ & $96(100)$ \\
\hline $\begin{array}{l}\text { Lack of opportunities to utilize } \\
\text { new skills in the work place }\end{array}$ & $32(33.3)$ & $6(66.7)$ & $96(100)$ \\
\hline $\begin{array}{l}\text { Lack of schools near the place } \\
\text { of residence }\end{array}$ & $36(37.5)$ & $6(62.5)$ & $96(100)$ \\
\hline $\begin{array}{l}\text { Managers not convinced that } \\
\text { staff development is of vital } \\
\text { importance to service }\end{array}$ & $71(74)$ & $25(26)$ & $96(100)$ \\
\hline Difficult entry requirements & $54(56.3)$ & $4(43.7)$ & $96(100)$ \\
\hline
\end{tabular}

\section{Discussion}

Barriball [26] reported some literatures that asserted the importance and pertinence of continuing professional education to nurses and it is unarguably clear that their commitment to learn and benefit from an educational experience is paramount in their professional education. Findings from our study depict that majority of the participants $(87 \%)$ would partake in continuing formal 
education in order to be abreast and up-to-date in their areas of specialization. This discovery is in tandem with previous study [36] in which most of the participants noted that continuing education keeps the practitioner up-to-date in their chosen career. Participants in our study seem to be consumer-driven in their practice as they overwhelmingly (96\%) sought for continuing formal education as a prerequisite to develop proficiency needed for patient care. This reason is very important in the contemporary nursing care practice considering the changing needs and increased awareness of consumer rights among Nigerian patients [11, 13-16]. The findingsfrom this study also pointed out that most of the nurses would like to participate in continuing formal education in order to gain knowledge and skills not readily available or not quite obtainable during their basic nursing programs $(83 \%)$. Others include to develop leadership capabilities (64\%), to be an effective mentor for junior nurses or nursing students $(90 \%)$ and to improve confidence $(96 \%)$. This is in agreement with the findings of Richard \&Potgiefer [3] and Baxter et al [37].It is not a gainsaying the fact that nurses who are well educated and are abreast of new trends in nursing, are likely to have increased morale and confidence in their professional practice [38]. Similarly, the finding shows that participants also identifiedother reasons asto plan a career pathway (64\%), to improve prospects of pay increase and promotion $(89 \%)$. This finding is in agreement with the findings of Hughes and Chong et al [2, 38] where most of the participants indicated that they will like to obtain additional qualification in order to meet up with requirement of promotion and the associated increase in pay.

Motivating factors that propelled nurses in this study to embrace continuing formal or professional education include management supports and encouragement(96\%), funding support $(95 \%)$,prospect of promotion and pay increase $(83 \%)$ and peer encouragement $(71 \%)$.Studies $[37,39-$ 40]havepointed out that the role of management in developing its manpower is essential in motivating the employees.Human resources are even the most important valuables in any setting [4] and healthcare facilities should create a culture and an enabling environment for continuing education of their employees [3]. Organizations that decline to invest in their employees stand the risk of being characterized by unmotivated employees which may lead to drop in productivity [4].In the same way, promotion is a key motivator in participants' quest for continuing education. This finding is not surprising considering that most of the participants $(87 \%)$ agreed that they were motivated by qualifications that carry skill allowance. Studies [2, 37 and 40] have corroborated our findings on funding supports as funding has been described as an unwavering necessity due to its association with financial resources. Lack of funding was identified as a major barrier by nearly all participants $(98 \%)$ in this study. This goes with studies [2, 36-37, 40-41] supporting the need for managements to provide the needed financial support in order to encourage nurses to keep abreast of current knowledge. Familial responsibilities such as child care and others were also identified as one major (95\%) barrier to continuing education among nurses in our study. This finding is similar to other findings [2, 36-37]where participants identified family responsibilities as barriers to nurses' engagement in continuing professional development. Although this study was not intended to capture data about the participants' marital status, individuals who are married may have in addition to their professional responsibility the need to cater for the immediate family. This may often interfere with personal and organizational needs of the individual. Most nurses (54\%) in this study hold professional diploma in nursing and only six $(6 \%)$ hold first degree in nursing (BNSc.). This may portend low participation in continuing formal or professional education in future. This is of great concern considering the impact of education on quality healthcare delivery to the patients.However, the finding is similar to the report from other studies [7, 42] which noted that most Nigerian nurses have only diploma certificates. It is expected that with increase in nursing programs in some of the universities in Nigeria including the National Open University, more nurses may enrol into the programs $[1,7]$.Like it is obtainable in developed countries, a strategy to improve nurses' educational status in Nigeria could be to amalgamate the schools of nursing into the universities that run nursing programs [43].

\subsection{Study Limitations}

Restricting the scope of our study to conference attendees bypassed those who did not attend the conferences for one reason or the other. Therefore, the outcome may not hold the impetus for generalization.

\section{Conclusion}

Nurses in this study expressed the need for motivations in order to undertake continuing professional education program. This is however, not available to the nurses. With largest percentage of the participants in this study holding only diploma certificate in nursing, the government and the management of healthcare organizations need to provide motivations such as funding, encouragement and increase manpower needed to facilitate continuing education by nurses.

\section{Acknowledgement}

The authors wish to acknowledge Umar Umar and Musa Waziri for assisting in the data collection. We also acknowledge the MCPDP committee of Niger state for granting the permission to conduct the study.

\section{References}

[1] E. Ayandiran, O. Omolola, O. Joel, G. Ntombi. Educational reforms in Nigeria: How responsive is the nursing profession? International Journal of Nursing Education Scholarship. 2013;10(1):1-8. 
[2] E. Hughes. Nurses' perception of continuing professional development. Nursing Standard. 2005;19(43): 41-49.

[3] L. Richards, E. Potgieter. Perception of registered nurses in four state institutions on continuing formal education. Curationis. 2010;33(2):41-50.

[4] World Health Organisation. The World Health Report. Health systems: Improving performance. World Health Organisation, Geneva; 2000.

[5] L. W. Eustace. Mandatory continuing education: past, present, and future trends and issues. The Journal of Continuing Education in Nursing. 2001;32 (3):133-137.

[6] C. Peck, M. McCall, T. Rotem. Continuing medical education and continuing professional development: International comparisons. British Medical Journal. 2000;320:432-435.

[7] C. Agbedia. Re-envisioning nursing education and practice in Nigeria for the 21st century. Open Journal of Nursing. 2012;2:226-230.

[8] I. T. Adeleke, S. A. Erinle, A. M. Ndana, T. C. Anamah, O. A. Ogundele, D. Aliyu. Health information technology in Nigeria Stakeholders' perspectives of nationwide implementations and meaningful use of the emerging technology in the most populous black nation. American Journal of Health Research. Special Issue: Health informationtechnology in developing nations: challenges and prospects health information technology. 2014;3(1-1):17-24. doi: 10.11648/j.ajhr.s.2015030101.13.

[9] I. T. Adeleke, M. A. Asiru, B. M. Oweghoro, A. B. Jimoh, A. M. Ndana. Computer and internet use among tertiary healthcare providers and trainees in a Nigerian public hospital. American Journal of Health Research.Special Issue: Health Information Technology in Developing Nations: Challenges and Prospects Health InformationTechnology. 2015;3(1-1):110. doi: 10.11648/j.ajhr.s.2015030101.11.

[10] I. T. Adeleke, A. H. Lawal, R. A. Adio, A. A. Adebisi. Information technology skills and training needs of health information management professionals in Nigeria: a nationwide study. Health Information Management Journal, 2014. doi.org/10.12826/18333575.2014.0002.Adeleke.

[11] B. M. Oweghoro, I. T. Adeleke, P. P. Mshelia, L. M. Ogundiran, A. M. J. Yusuf, D. I. Adeoti. Knowledge, access and use of internet-based health information for personal healthcare among employees of the foremost Nigerian University. AmericanJournalofHealthResearch. Special Issue: Health Information Technology in Developing Nations: Challenges and Prospects Health Information Technology. 2015;3(1-1):25-31. doi: 10.11648/j.ajhr.s.2015030101.14

[12] I. T. Adeleke, A. A. Salami, M. Achinbee, T. C. Anamah, I. B. Zakari, M. H. Wasagi. ICT knowledge, utilization and perception among healthcare providers at National Hospital Abuja, Nigeria. AmericanJournalofHealthResearch. Special Issue: Health Information Technology in Developing Nations: Challenges and Prospects Health Information Technology(in press).

[13] S. A. Adefemi, I. T. Adeleke, P. Gara, O. O. Abdulghaney, S. A Omokanye, A. M. J. Yusuf. The rate, reasons and predictors of hospital discharge against medical advice among inpatients of a tertiary health facility in North-central Nigeria. American Journal of Health Research. Special Issue: Health Information Technology in Developing Nations: Challenges and Prospects Health Information Technology. 2014;3(1-1):11-16. doi: 10.11648/j.ajhr.s.2015030101.12.

[14] A. O. Adekanye, S. A. Adefemi, A. G. Okuku, K. A. Onawola, I. T. Adeleke, J. A. James. Patients' satisfaction with the healthcare services at a North-central Nigerian tertiary hospital. Niger J Med. 2013;22(3):218-224.

[15] D. Aliyu, I. T. Adeleke, S. O. Omoniyi, B.A. Samaila, A. Adamu, A. Y. Abubakar. Knowledge, attitude and practice of nursing ethics and law among nurses at Federal Medical Centre, Bida. AmericanJournalofHealthResearch. Special Issue: Health Information Technology in Developing Nations: Challenges and Prospects Health Information Technology. 2015; 3(1-1): 32-37. doi: 10.11648/j.ajhr.s.2015030101.15.

[16] I. T. Adeleke, A. O. Adekanye, S. A. Adefemi, et al, Knowledge, attitude and practice of confidentiality of patients' health records among healthcare professionals at Federal Medical Centre, Bida. Niger J Med. 2011;20(2):228-235.

[17] I. T. Adeleke, A. O. Adekanye, K. A. Onawola, et al. Data quality assessment in healthcare: a 365-day chart review of inpatients' health records at a Nigeria tertiary hospital. J Am Med Inform Assoc 2012;19:1039-1042doi: 10.1136/amiajnl2012-00823.

[18] I. T. Adeleke, O. O. Ajayi, A. B. Jimoh, A. A. Adebisi, S. A. Omokanye, M. K. Jegede. Current clinical coding practices andimplementation of ICD-10 in Africa: a survey of Nigerian Hospitals. AmericanJournalofHealthResearch. Special Issue: Health Information Technology in Developing Nations: Challenges and Prospects Health Information Technology. 2015; 3(1-1): 38-46. doi:10.11648/j.ajhr.s.2015030101.16

[19] D. Aliyu, I. T. Adeleke, S. O. Omoniyi, S. Kolo, O. M. Odofin, P. E. Ekaete. Knowledge, attitude and practice of preoperative visit: a survey of Nigerian perioperative nurses. AmericanJournalofHealthResearch. Special Issue: Health Information Technology in Developing Nations: Challenges and Prospects Health Information Technology (in press).

[20] J. Stanford. Continuing education. Joumal of District Nursing. $1989 ; 12: 8-10$.

[21] J.Barber The tip of the iceberg. The Canadian Nurse. 1977;73(1):34-35.

[22] L. Gallagher. Continuing education in nursing: A concept analysis. Nurse Education Today. 2007;27:466-473.

[23] L. D. Xiao. Nurse educators' perceived challenges in mandatory continuing nursing education. International Nursing Review. 2006;53:217-223.

[24] S. Ehrat. Executive nurse career progression: skills, wisdom and realities. Nursing Administration Quarterly. 2001;25(4):36-42.

[25] L. W. Eustace. Mandatory continuing education: Past, present, and future trends and issues. The Journal of Continuing Education in Nursing. 2001;32(3):133-137.

[26] K. L. Barriball, A. E. While, I. J. Norman. Continuing professional education forqualified nurses: a review of the literature. Journal of Advanced Nursing. 1992;17:1129-1140.

[27] M. Nolan, R. Owens, J. Nolan. Continuing professional education: identifying the characteristics of an effective system. Journal of Advanced Nursing. 1995;21:551-560.

[28] R. D. Fox, N. L. Bennett. Learning and change: implications for continuing medical education. BMJ. 1998;316:466-468. 
[29] D. Davis, M. A. T. O’Brien, N. Freemantle, F. M. Wolf, P. Mazmanian, A. Taylor-Vaisey. impact of formal continuing medical education do conferences, workshops, rounds, and other traditional continuing education activities change physician behaviour or healthcare outcomes?JAMA. 1999;282:867-874.

[30] L. Richard, E. Potgieter. Perceptions of registered nurses in four state health insititutions on continuing formal education. Curationis. 2010;41-50.

[31] R. Grol, J. Grimshaw. From best evidence to best practice: effective implementation of change in patients' care. The Lancet. 2003;362:1225-30.www.thelancet.com.

[32] P. R. Zuzelo. Exploring the moral distress of registered nurses. Nursing Ethics. 2007;14(3):344-359.

[33] P. E. Mazmanian, D. A. Davis. Continuing medical education and the physician as a learner: guide to the evidence. JAMA. 2002;288(9):1057-1060. doi:10.1001/jama.288.9.1057.

[34] L. Kristjanson, J. Scanlon. Assessment of continuing nursing education needs: a literature review. Journal of Continuing Education in Nursing. 1992;23(4):156-160.

[35] M. Nolan, R. Owens, J. Nolan, J. Continuing professional education: identifying the characteristics of an effective system. Journal of Advanced Nursing. 1995;21:551-560.

[36] C. Cooley. Nurses' motivations for studying third level post registration programs and the effect of studying on their personal and work lives. Nurse Education Today. 2008;28:588-594.
[37] P. Baxter, A. DiCenso, F. Donald, R. J. Martin-Misena, T. Chambers. Continue education for primary health care nurses practicing in Ontario, Canada. Nurse Education Today, 2012. http://dx.doi.org/10.1016/j.nedt.2012.07.018.

[38] M. Chong, S. Kenneth, K. Francis, K. Abdullah. What influence Malysians nurses to participate in continuing professional development activities. Asian Nursing Research. 2011;5(1):38-47.

[39] Y. Chiu, C. Tsai, C. Chiang. (2013). the relationships among nurses' job characteristics and attitudes towards web-based continuing learning. Nurse Education Today, 2013. http://dx.doi.org/10.1016/j.nedt.2013.01.01.

[40] D. Gould, E. Berridge. Nurses experiences of continuing professional development. Nurse Education Today. 2007;27:602-609.

[41] K. Penz, C. D'Arcy, N. Stewart, J. Kosteniuk, B. Smirth. (2007). Barriers to participation in continuing education activities among ruaral and remote nurses. Journal of Continuing Education in Nursing. 2007;38(2):58-66.

[42] A. Ojo. The challenges of best practices and standards in nursing in Nigeria. Paper presented at the 4th (2010) inaugural lecture series, Igbinediom University, Okada, Edo State, Nigeria.

[43] E. Danielson, L. Berntsson. Registerednurses' perceptions of educational preparation for professional work and evelopment in their profession. Nurse education today, 2007;27(900908). 